\title{
COMP wt Allele
}

National Cancer Institute

\section{Source}

National Cancer Institute. COMP wt Allele. NCI Thesaurus. Code C131263.

Human COMP wild-type allele is located in the vicinity of 19p13.1 and is approximately 9 $\mathrm{kb}$ in length. This allele, which encodes cartilage oligomeric matrix protein, is involved in cartilage structural integrity. Mutation of the gene is associated with pseudoachondroplasia and multiple epiphyseal dysplasia 1. 